\title{
GAMBARAN PENGETAHUAN IBU TENTANG PIJAT BAYI DI DESA DAJAN PEKEN TABANAN
}

\author{
Cokorda Istri Mita Pemayun ${ }^{1,2}$, Rini Winangsih ${ }^{1,2}$, Ni Made Dwi Endah Pratiwi ${ }^{1,2}$ \\ ${ }^{1}$ Program Studi Diploma III Kebidanan, ${ }^{2}$ STIKes Advaita Medika Tabanan \\ Korespodensi penulis: mid.cokp@gmail.com
}

\begin{abstract}
Abstrak
Latar belakang: Kurangnya rangsangan yang diberikan pada bayi menambah keterlambatan perkembangan bayi. Pijat bayi ini perlu diketahui oleh seorang ibu karena dengan sentuhandan pandangan mata saat pemijatan akan mampu mengalirkan kekuatan jalinan kasih saying diantara keduanya.

Tujuan: Adapun tujuan dari penelitian ini yaitu untuk mengetahui gambaran pengetahuan ibu tentang pijat bayi di Desa Dajan Peken Tabanan.

Metode: Dalam penelitian menggunakan metode deskriptif kuantitatif yang dilaksanakan di Desa Dajan Peken Tabanan pada Bulan September 2020. Sampel dalam penelitian ini adalah ibu yang memiliki bayi usia $0-12$ bulan yang berjumlah 33 orang dan diambil secara total sampling. Instrumen dalam penelitian ini menggunakan lembar kuesioner. Teknik analisa data menggunakan analisa univariat.

Hasil: Hasil penelitian yaitu pengetahuan ibu tentang pijat bayi di Desa Dajan Peken Tabanan sebagian besar dalam kategori cukup yaitu sebanyak 22 orang $(66,7 \%)$.

Simpulan: dalam penelitian ini yaitu gambaran pengetahuan ibu tentang pijat bayi di Desa Dajan Peken Tabanan sebagian besar cukup sebanyak 22 responden $(66,7 \%)$.
\end{abstract}

Kata kunci: Pengetahuan ibu, Pijat bayi

\section{Pendahuluan}

Masa tumbuh kembang bayi merupakan masa keemasan, karena pada masa bayi berlangsung sangat singkat dan tidak dapat diulang, dimana pada masa ini bayi sangat peka terhadap lingkungan dan stimulasi yang baik untuk pertumbuhan dan perkembangannya (Kementrian Kesehatan RI, 2009). Setiap bayi harus mendapat stimulasi rutin secara dini pada setiap perkembangannya (Sulistyawati, 2014). Stimulasi yang diberikan kepada bayi sangat berperan penting bagi pertumbuhan fisik dan perkembangan emosional, terutama dalam usia 2 tahun pertama yang akan menentukan perkembangan kepribadian anak (Daniati dan Novayelinda, 2011). Menurut Widyastuti dan Widyani (2008), jenis-jenis stimulasi yang dapat diberikan kepada anak adalah stimulasi visual, pendengaran, kinetic dan sentuhan. Salah satu bentuk stimulasi yang selama ini yang dilakukan oleh masyarakat adalah pijat bayi (Prasetyono dan Putri, 2009). Pijat bayi disebut juga terapi sentuh karena melaluipijatbayiinilahakanterjadikomunikasi yangnyamandanamanantara ibu dan buah hatinya (Riksani,2012). Penelitian yang dilakukan oleh Thulil Kurrota Ayun (2018) yang melakukan penelitian tentang hubungan antara pengetahuan ibu tentang pijat bayi terhadap perilaku ibu dalam melakukan pijat bayi di Desa Ceweng Kecamatan Diwek Kabupaten Jombang menunjukkan hasil pengetahuan ibu tentang pijat bayi didapatkan 38 responden berpengetahuan cukup $(60,3 \%)$. Penelitian yang dilakukan oleh Dewi Indriyani (2014) yang melakukan penelitian tentang gambaran pengetahuan ibu tentang pijat bayi di Desa Raci Kecamatan Batangan Kabupaten Pati, hasil penelitian menunjukkan pengetahuan ibu tentang pengertian pijat bayi sebagian besar 
berpengetahuan baik sebanyak 77 responden (82.8).

Menurut WHO (2017), secara global sekitar 20-40 persen bayi usia 0-2 tahun mengalami masalah keterlambatan dalam proses perkembangan. Prevalensi masalah perkembangan anak di berbagai negara maju dan berkembang diantaranya Amerika sebesar 12-16 persen, Argentina 22 persen dan Hongkong 23 persen, serta beberapa penelitian yang telah di evaluasi berdampak kegagalan bahkan memperpendek usia hidup (Bhaudari, 2017). Menurut Depkes RI (2006), menyatakan bahwa 16 persen bayi di Indonesia mengalami gangguan perkembangan saraf dan otak mulai dari ringan sampai berat. Kurangnya rangsangan yang diberikan pada bayi menambah keterlambatan perkembangan bayi (Soetjiningsih, 2014). Para ahli di Fakultas Kedokteran Universitas Miami sejak 1986 meneliti tentang manfaat pijat bayi dan terbukti perkembangan berat badan bayi premature yang dipijat mengalami kenaikan berat badan 20-40 persen dibandingkan dengan bayi yang tidak dipijat (Kartini,2014). Pemijatan dimulai sejak bayi usia 4 minggu yang dilakukan oleh ibunya setiap satu sampai dua kali sehari, ternyata mendapatkan hasil yang menunjukkan perbedaan pertumbuhan berat badan yang sangat bermakna (Rosalina, 2007). Ilmu kesehatan tentang pijat bayi masih belum banyak diketahui oleh masyarakat (Prasetyono, 2009).

Informasi yang didapat di Desa Dajan Peken Kabupaten Tabanan terdapat 103 bayi yang berusia $0-12$ bulan, dari $10 \mathrm{ibu}$ yang di wawancarai hasil yang didapatkan, dari $7 \mathrm{ibu}$ yang ditanya tentang pijat bayi, 1 ibu yang mengetahui pengertian dan manfaat pijat bayi, 3 ibu yang mengetahui tentang manfaat pijat bayi dan 3 yang lain tidak mengetahui tentang pijat bayi. Pemijatan bayi di masyarakat masih merupakan hal yang awam. Seperti halnya di Desa Dajan Peken, Tabanan, kebiasaan hanya memijatkan bayinya pada saat sakit saja seperti saat flu dan masuk angin. Teknik pijatan yang tepat dilakukan secarateraturkepadabayi dan balita baik dalam keadaan sehat maupun sakit bisa dilakukan kapan pun dan baik juga dilakukan saat sikecil dalam kondisi sehat maupun sakit seperti flu maupun masuk angin (Riksani, 2012). Ibu harus mengetahui teknik pijat bayi dan mampu melaksanakannya secara mandiri agar tercipta bounding attachment.

Pijat bayi ini perlu diketahui oleh seorang ibu karena dengan sentuhandan pandangan mata antara orang tua dan bayi pada saat pemijatan akan mampu mengalirkan kekuatan jalinan kasih saying diantara keduanya yang merupakan dasar komunikasi untuk memupuk cinta kasih secara timbal balik, mengurangi kecemasan, meningkatkan kemampuan fisik serta rasa percayadiri (Aminati, 2013).

\section{Metode Penelitian}

Penelitian ini menggunakan metode deskriptif kuantitatif. Penelitian deskriptif merupakan penelitian yang di dalamnya tidak ada analisis hubungan antar variabel, tidak ada variabel bebas dan terikat, bersifat umum yang membutuhkan jawaban di mana, kapan, berapa banyak, siapa, dan analisis statistik yang digunakan adalah deskriptif (Hidayat,2011). Lokasi penelitian dilaksanakan di Desa Dajan Peken Tabanan. Waktu pengambilan data dilaksanakan pada bulan Agustus 2020. Sampel dalam penelitian ini adalah ibu yang memiliki bayi di Desa Dajan Peken Kabupaten Tabanan. Pengambilan sampel menggunakan teknik total sampling yaitu mengambil seluruh populasi sebagai sampel yang berjumlah 33 orang (Sugiyono, 2014). Dalam penelitian ini analisis univariat yang dilakukan adalah mendistribusikan karakteristik responden yaitu umur, pendidikan dan pekerjaan serta mendistribusikan gambaran pengetahuan ibu tentang pijat bayi. 
3. Hasil dan Pembahasan

Tabel 1 Karakteristik Responden

\begin{tabular}{ccc}
\hline Umur & Frekuensi & Persentase (\%) \\
\hline $20-30$ tahun & 31 & 93,9 \\
31-40 tahun & 2 & 6,1 \\
$>40$ th & - & - \\
\hline Pekerjaan & 5 & 15,1 \\
\hline Tidak bekerja & 10 & 30,3 \\
Karyawan & 2 & 6,1 \\
\hline PNS & 16 & 48,5 \\
\hline Wiraswasta & & \\
\hline Pendidikan & 1 & 3,0 \\
\hline SD & - & - \\
SMP & 26 & 78,8 \\
\hline SMA/SMK & 5 & 15,2 \\
\hline Diploma & 1 & 3,0
\end{tabular}

Tabel 2 Gambaran Pengetahuan Ibu Tentang Pijat Bayi

\begin{tabular}{|c|c|c|}
\hline Tingkat Pengetahuan & Frekuensi & Persentase (\%) \\
\hline \multicolumn{3}{|c|}{ Pengetahuan ibu tentang pengertian pijat bayi } \\
\hline Baik & 5 & 15,2 \\
\hline Cukup & 24 & 72,7 \\
\hline Kurang & 4 & 12,1 \\
\hline Total & 33 & $100 \%$ \\
\hline \multicolumn{3}{|c|}{ Pengetahuan ibu tentang manfaat pijat bayi } \\
\hline Baik & 6 & 18,2 \\
\hline Cukup & 23 & 69,7 \\
\hline Kurang & 4 & 12,1 \\
\hline Total & 33 & 100 \\
\hline \multicolumn{3}{|c|}{ Pengetahuan ibu tentang teknik pijat bayi } \\
\hline Baik & 7 & 21,2 \\
\hline Cukup & 21 & 63,6 \\
\hline Kurang & 5 & 15,2 \\
\hline Total & 33 & 100 \\
\hline \multicolumn{3}{|c|}{ Pengetahuan ibu tentang indikasi pijat bayi } \\
\hline Baik & 5 & 15,2 \\
\hline Cukup & 25 & 75,8 \\
\hline Kurang & 3 & 9,1 \\
\hline Total & 33 & 100 \\
\hline \multicolumn{3}{|c|}{ Gambaran pengetahuan ibu tentang pijat bayi } \\
\hline Baik & 6 & 18,2 \\
\hline Cukup & 22 & 66,7 \\
\hline Kurang & 5 & 15,1 \\
\hline Total & 33 & 100 \\
\hline
\end{tabular}

Pada tabel 1 dapat dijelaskan bahwa dari 33 respondensebagian besar berusia 20-30 tahun yaitu sebanyak $31(93,9 \%)$ responden, sebagian besar bekerja sebagai wiraswasta sebanyak 16 responden $(48,5 \%)$ dan sebagian besar berpendidikan SMA/SMK sebanyak 26 responden $(78,8 \%)$. Berdasarkan tabel 2 dapat dijelaskan bahwa pengetahuan ibu tentang pengertian pijat bayi sebagian besar cukup sebanyak 24 responden (72,7\%), pengetahuan ibu tentang manfaat pijat bayi sebagian besar cukup 
sebanyak 23 responden $(69,7 \%)$, pengetahuan ibu tentang teknik pijat bayisebagian besar cukup sebanyak 21 responden $(63,6 \%)$, pengetahuan ibu tentang indikasi pijat bayi sebagian besar cukup sebanyak 25 responden $(75,8 \%)$ dan gambaran pengetahuan ibu tentang pijat bayi sebagian besar cukup sebanyak 22 responden $(66,7 \%)$.

Hasil penelitian menunjukkan bahwa sebagian besar responden memiliki pengetahuan yang cukup. Menurut Notoatmodjo (2011), pengetahuan adalah hasil tahu dan ini terjadi setelah orang melakukan penginderaan terhadap suatu objek tertentu. Penginderaan terjadi melalui panca indera manusia yaitu indera penglihatan, pendengaran, penciuman, rasa, dan raba. Sebagian besar pengetahuan manusia diperoleh melalui mata dantelinga.

Menurut Wawan dan Dewi (2011), faktor-faktor yang mempengaruhi tingkat pengetahuan dibagi menjadi dua yaitu: 1) Faktor internal yang meliputi pendidikan, pekerjaan, umur; 2) Faktor eksternal yang meliputi lingkungan dan sosial budaya. Pendidikan mempengaruhi proses belajar makin tinggi pendidikan seseorang semakin mudah pula mereka menerima informasi, dan akhirnya makin banyak pula pengetahuan yang dimiliki. Berdasarkan penelitian didapatkan hasil responden yang memiliki tingkat pendidikan Sarjana (3,0\%), Diploma $(15,2 \%)$, SMA/SMK (78,8\%), dan SD $(3,0 \%)$. Dari data tersebut tingkat pendidikan Sarjana memiliki tingkat pengetahuan baik, tingkat pendidikan Diploma dan SMA/SMK rata-rata memiliki tingkat pengetahuan baik dan cukup, dantingkat pendidikan SD memiliki tingkat pengetahuan kurang.

Pekerjaan dapat menjadikan seseorang memperoleh pengalaman dan pengetahuan baik secara langsung maupun tidak langsung. Sebaliknya orang yang tidak memiliki pekerjaan mereka tidak akan memiliki banyak pengalaman sehingga pengetahuan yang didapat juga kurang. Berdasarkan hasil penelitian didapatkan ibu yang bekerja sebagai wiraswasta $(48,5 \%)$, karyawan $(30,3 \%)$ tidak bekerja $(15,1 \%)$ dan PNS
(6,1\%). Dari data tersebut ibu yang bekerja sebagai PNS dan karyawan rata-rata memiliki tingkat pengetahuan baik dan cukup, sedangkan ibu yang bekerja sebagai wiraswasta memiliki tingkat pengetahuan cukup, dan ibu yang tidak bekerja rata-rata memiliki tingkat pengetahuan cukup dan kurang.

Usia mempengaruhi pengetahuan seseorang, semakin cukup umur, tingkat kematangan dan kekuatan seseorang akan lebih matang dalam berfikir dan bekerja (Notoatmodjo, 2011). Berdasarkan hasil penelitian didapatkan ibu yang sebagian besar ibu memiliki usia 20-30 tahun (93,9\%), usia 30-40 tahun $(6,1 \%)$ dan tidak ada yang berusia $>40$. Dari data tersebut ibu yang usianya 20-30 tahun rata-rata memiliki tingkat pengetahuan cukup dan kurang, sedangkan ibu yang usianya 30-40 tahun rata-rata memiliki tingkat pengetahuan baik dan cukup.

Lingkunganmerupakanseluruhkondisiyan gadadisekitarmanusiadan pengaruhnya yang dapat mempengaruhi perkembangan dan perilaku orang atau kelompok. Jika lingkungan tersebut adalah lingkungan mayoritas penduduk memiliki pendidikan rendah maka tingkat pengetahuan yang didapatkan juga rendah begitupun sebaliknya, apabila mayoritas penduduknya memiliki pendidikan yang tinggi maka seseorang akan memiliki pengetahuan yang tinggi. Informasi memberikan kemudahan untuk memperoleh suatu informasi dapat membantu mempercepat seseorang untuk memperoleh pengetahuanbaru.

Sosial budaya juga mempengaruhi seseorang dalam mendapatkan informasi dan juga pengetahuan. Informasi lebih mudah diperoleh ketika seseorang tersebut berada di wilayah perkotaan dengan kebiasaan hidup mewah dan kecanggihan teknologi yang bisa mereka dapat semakin mempermudah untuk memperoleh informasi dan juga tambahan pengetahuan sedangkan masyarakat yang hidup di desa mayoritas informasi yang mereka miliki juga kurang, karena masih banyak adat-istiadat yang sangat kental yang masih diterapkan di desa (Notoatmodjo, 
2011).

Hasil penelitian menunjukkan sebagian besar responden dengan tingkat pengetahuan cukup namun kurang mengetahui manfaat pijat bayi, waktu mulai pijat bayi dan teknik pijat bayi. Menurut Roesli (2008), manfaat pijat bayi terbagi dua yaitu 1) Dampak biokimia yang positif, 2) Dampak klinis yang positif. Dampak klinis yang positif salah satunya sebagai merangsang fungsi pencernaan serta pembuangan. Menurut Riksani (2012), waktu mulai pijat bayi bisa dilakukan segera setelah bayi lahir, sesuai dengan keinginan. Bayi akan mendapatkan manfaat dan keuntungan lebih besar. Hasil yang lebih optimal akan didapatkan jika pemijatan dilakukan sejak bayi lahir secara teratur setiap hari hingga bayi berusia 6-7 bulan. Menurut Roesli (2008), salah satu teknik pijat bayi adalah gerakan peregangan lembut. Gerakan-gerakan sederhana yang meregangkan tangan dan kaki bayi, dapat berupa sentuhan pada bagian perut bayi dan panggul serta gerakan yang bertujuan meluruskan tulang belakang. Gerakan peregangan lembut dapat dilakukan sebanyak 4-5 kali setiap gerakan.

Berdasarkan penelitian yang pernah dilakukan oleh Astuti (2013), dengan judul "Tingkat Pengetahuan Ibu tentang Pijat Bayi di BPS Suratini Soewarno Mojosongo Surakarta" dengan 31 responden diperoleh hasil penelitian yaitu tingkat pengetahuan baik sebanyak 5 responden (16\%), tingkat pengetahuan cukup sebanyak 19 responden (61\%), dan tingkat pengetahuan kurang sebanyak 7 responden (23\%). Dari hasil pengetahuan tersebut tingkat pengetahuan yang paling banyak pada kategori tingkat pengetahuan cukup yaitu sebanyak 19 responden $(61 \%)$.

Berdasarkan hasil penelitian dapat disimpulkan bahwa gambaran pengetahuan ibu tentang pijat bayi diDesa Dajan Peken Tabanan sebagian besar pada kategori cukup yaitu 22 responden $(66,7 \%)$,yang dipengaruhi oleh pendidikan, pekerjaan, umur serta lingkungan dan sosial budaya.

\section{Simpulan}

Simpulan dari penelitian ini adalah gambaran pengetahuan ibu tentang pijat bayi di Desa Dajan Peken Tabanan sebagian besar cukup sebanyak 22 responden $(66,7 \%)$.

\section{Referensi}

Aminati, D. 2013. Pijat dan Senam untuk Bayi \& Balita. Yogyakarta : Brilliant Books

Arikunto,S.2013.ProsedurPenelitianSuatuPe ndekatanPraktik.Jakarta:Rineka Cipta

Astuti, L. 2013. Tingkat Pengetahuan Ibu tentang Pijat Bayi di BPS Suratini Soewarno Mojosongo Surakarta. STIKes Kusuma Husada Surakarta. Karya Tulis Ilmiah

Dewi, V.N.L. 2011. Asuhan Neonatus Bayi dan Anak Balita. Jakarta : Salemba Medika

Hidayat, A. 2011. Metode Penelitian Keperawatan dan Teknik Analisis Data. Jakarta : Salemba Medika

Muslihatun,W.N.2010.AsuhanNeonatusBayi danBalita.Yogyakarta:Fitramaya

Notoatmodjo, S. 2011. Kesehatan Masyarakat Ilmu \& Seni. Jakarta : RinekaCipta

Notoatmodjo, S. 2011. 2012. Metodologi Penelitian Kesehatan. Jakarta : Rineka Cipta

Oktobriariani, R. 2010. Pengaruh Pendidikan Kesehatan tentang Pijat Bayi terhadap Praktik Pijat Bayi di Polindes Harapan Bunda Sukoharjo. UNS Surakarta. Karya Tulis Ilmiah

Riksani, R. 2012. Cara Mudah \& Aman Pijat Bayi. Jakarta Timur : Dunia Sehat

Riwidikdo,H.2013.StatistikuntukPenelitianK esehatandenganAplikasiProgram $R$ dan SPSS. Yogyakarta : Pustaka Rihama

Roesli, U. 2008. Pedoman Pijat Bayi Prematur \& Bayi Usia 0-3 Bulan. Jakarta: Trubus Agriwidya

Santi, E. 2012. Buku Pintar Pijat Bayi untuk Tumbuh Kembang Optimal, Sehat \& Cerdas. Yogyakarta : Pinang Merah Publisher 
Saragih, D. 2010. Panduan Praktik Keperawatan Bayi dan Anak. Yogyakarta : Citra Aji Parama

Saryono. 2011. Metodologi Penelitian Kesehatan Penuntun Praktis Bagi Pemula. Yogyakarta : Mitra Cendika Press

Soetjiningsih. 2012. Tumbuh Kembang Anak. Jakarta : EGC

Sugiyono. 2012. Metode Penelitian Kuantitatif, Kualitatif, dan $R \& D$. Bandung : Alfabeta

Sulistyawati, A. 2014. Deteksi Tumbuh Kembang Anak. Jakarta : Salemba Medika

Wawan,AdanDewi,M.2011.Teori\&Penguku ran,Sikap,danPerilakuManusia. Yogyakarta: Nuha Medika 